\title{
Sensory Evaluation of Value Added Dairy Products using Bael Pulp (Aegle marmelos) and Stevia Powder
}

\author{
Amarjeet Kaur $^{1 *}$, Anita Kochhar ${ }^{1}$, Savita Sharma ${ }^{2}$ and R. S. Boora ${ }^{3}$ \\ ${ }^{1}$ Department of Food \& Nutrition, College of Home Science, Punjab Agricultural University, \\ Ludhiana-141004, India \\ ${ }^{2}$ Senior Dough Rheologist, Deptt of Food Science and Technology, PAU, Ludhiana, India \\ ${ }^{3}$ Horticulturist, Regional Fruit Research Station, Bahadurgarh, Patiala, India
}

*Corresponding author

\section{A B S T R A C T}

\section{Keywords}

gajrela, burfi, milk, organoleptic

evaluation, sugar,

stevia, proximate analysis

Article Info

Accepted:

20 August 2019

Available Online:

10 September 2019
Aegle marmelos also known as bael is being used in traditional medicinal system since ancient times. This tree belonging to family Rutaceae contains many phytochemicals making it suitable for use in treatment and prevention of many common ailments. The chemical compounds isolated from this fruit are proven to be effective against many non communicable diseseas like CVDs, diabetes and cancer. Stevia(Stevia rebaudiana) is called honey leaf in Indian market. It can be easily grown in house gardens, pots or as a commercial field crop. As the demand of low carbohydrate sweetener is increasing now a days, Stevia can soon become the King of sweeteners. Stevia is a natural calorie free product but at the same time it is 300 times sweeter than sucrose. Considering the benefits of these two plants value added sweet milk products like gajrela and burfi were prepared using different proportions of bael pulp and stevia powder and sensory and proximate analysis of the products were done. Stevia was added to replace sugar at different levels.

\section{Introduction}

Bael (Aegle marmelos) possesses excellent therapeutic and nutritive value and has high a potential for processing in to a variety of quality products (Mandal and Sahoo 2014). The presence of carotenoids are responsible for the pale colour of the fruit. The therapeutically active principle components of bael fruit include marmelosin, umbelliferone and skimmianine (Hiremarh et al., 1996). About 28 volatile compounds are recognized in the bael pulp, foremost being the sesquiterpenes and monoterpenes like 
limonene, $\mathrm{p}$-Cymene, $\beta$-Phellandrene, and Dihydro- $\beta$-Ionone. These constituents contribute to the aroma fruit.

The characteristic bael fruit flavor is due to the presence of limonene, a key constituent among these compounds (Charoensiddhi and Anprung 2008). Baelpossesses many therapeutic properties including antidysentric, demulcent, astringent, antidiarrhoeal, anti inflammatory and antipyretic activities. It has been proved that the constituents purified from this fruit are biologically active in fighting against several major diseases like diabetes, cancer and cardio vascular diseases (Maity et $a l .$, 2009). The growing need for an alternate source of sugar for control of micro and macro vascular disorders related with diabetes and other diseases cannot be ignored. Sugar substitutes in the form of natural sweeteners are frequently promoted as healthier and better options than processed table sugar. Stevia (Stevia rebaudiana) is commonly used as a sweet natural sugar (Panchal et al., 2014). Stevia rebaudiana is a natural sweetest nutrient rich plant belonging to Asteraceae family that naturally grows in South America.

More than 200 species of stevia are found in the world but Stevia rebaudiana is the only species that possesses the characteristic of sweetening. Stevia leaves contain certain constituents i.e., glycosides which imparts a sweet taste but gives no caloric value (Kim et al., 2002).

\section{Materials and Methods}

\section{Procurement and processing of raw material}

The bael fruit (var. Kaghzi), was provided by Regional Research Station, Patiala, Punjab. Stevia powder was purchased from Ozzy Business Consulting Ltd, Patiala. Milk, khoa, carrots, sugar etc. were purchased from the local market of Ludhiana. The bael fruit was procured and checked for any infestation or damage. The fruit was washed and then broken by hitting on floor or using a hammer. The pulp along with seeds and fibres was scooped out of the fruit with help of a stainless steel spoon and the peel was discarded. The scooped out pulp was then weighed and equal amount of water was added to the pulp. It was then mixed in a mixer and sieved through a 20 mesh stainless steel to separate the seeds. The pulp thus obtained was used for the product development.

The recipe of the product with most acceptable level of bael pulp and stevia:

\section{Gajrela}

\section{Ingredients}

$\begin{array}{lll}\text { Milk } & - & 250 \mathrm{ml} \\ \text { Khoa } & - & 10 \mathrm{~g} \\ \text { Carrots } & - & 80 \mathrm{~g} \\ \text { Bael pulp } & - & 20 \mathrm{~g} \\ \text { Sugar } & - & 6 \mathrm{~g} \\ \text { Stevia powder } & - & 20 \mathrm{mg}\end{array}$

\section{Method}

Cleaned and grated the carrots.

Cooked them in milk till it thickened.

Khoa and sugar was added and cooked for 2-3 minutes. Added bael pulp and stevia powder, mixed well and cooked for 1 minute. The recipe of the product with most acceptable level has been given below:

\section{Burfi}

\section{Ingredients}

$\begin{array}{lll}\text { Milk } & - & 500 \mathrm{ml} \\ \text { Khoa } & - & 120 \mathrm{~g} \\ \text { Bael pulp } & - & 80 \mathrm{~g} \\ \text { Sugar } & - & 12 \mathrm{~g} \\ \text { Stevia powder } & - & 90 \mathrm{mg}\end{array}$




\section{Method}

Milk was boiled until it thickened.

Khoa and sugar was added and cooked again.

Added bael pulp and stevia and cooked for 2-3 minutes

Set the prepared burfi in a greased plate, cooled and cut in small pieces.

\section{Sensory Evaluation}

The organoleptic evaluation of the developed value added sweet products was carried out to select the most acceptable level of bael pulp from the first trial as well as the acceptable level of stevia powder in the development of products in the second trial. In the second trial, the acceptable product of first trial was used as the control sample. The sensory evaluation of the developed products first trial was carried out by ten trained panelists including faculty of department of Food and Nutrition of Punjab Agricultural University while the second trial was evaluated by both the trained panel as well as diabetic panel. The panel was provided with 9 point hedonic scale for attributes like appearance, colour, texture, flavour, taste and overall acceptability (Larmond 1970).

\section{Statistical Analysis}

The data on organoleptic evaluation and chemical analysis was analyzed statistically. Kruskal Wallis test was used for selecting the best formulations through sensory evaluation.

\section{Results and Discussion}

Sensory evaluation of milk based value added products with bael pulp/powder and stevia powder.

The sensory evaluation of gajrela and burfi was carried out to select the most acceptable proportion of bael pulp in all the products. The product with highest overall acceptability was used as control for second standardization and stevia was added in four other treatments. The product thus prepared incorporating bael pulp and stevia powder was then evaluated for sensory parameters by semi trained panel and diabetic panel. The mean scores of different parameters in control and test recipes with bael pulp are presented below:

\section{Gajrela incorporated withbael pulp}

Five samples were being prepared including one control in which only carrots were used as a base ingredient. The percentage of carrots was reduced and bael pulp was incorporated at the 10,20, 30 and 40 percent levels in the treatments designated as B1, B2, B3 and B4 respectively (Table 5).A significant difference was observed when evaluated statistically, in all the sensory parameters including appearance, colour, texture, flavour, taste and overall acceptability. The highest scores for overall acceptability was scored by B2 (7.87)followed by C (7.58) and B1 (7.54). The overall acceptability decreased as the percentage of bael pulp was increased. The B2 treatment scored highest in taste i.e., 7.75 followed by B1 (7.6) and C (7.5). The mean scores of all the parameters of B2 treatment were observed to be higher i.e., 7.75-8.0 as compared to C i.e., 7.5-7.7.

Gajrela incorporated with bael pulp and stevia powder by semi-trained panel

The difference in scores was found to be statistically significant with regard to all the sensory parameters as judged by semi trained panel. The highest mean scores for different sensory parameters of Gajrela were observed for BS2 followed by control (C) and BS1 treatments as shown in Table 6 and Fig.1. The BS1 and BS2 treatments were comparable to control (C) treatment for sensory parameters such as appearance, texture, aroma, taste and overall acceptability. The test treatments were 
significantly different from BS2 treatment in terms of all sensory parameters. The overall acceptability scores for theBS2 (7.95) followed by C (7.59), BS1 (7.37),BS3 (6.94) and BS4 with a minimum score of 6.63. Vyoma and Kochhar (2008) revealed that replacing sugar with stevia in preparation of gajrela scored an overall acceptability score of 7.7 and hence decreasing the calorie intake. The scores given by the diabetic panel for the modified recipe with $50 \mathrm{mg}$ steviocal was i.e., $7.7 \pm 0.17$ and taste scores ranged from $6.9 \pm 0.24$ to $8.0 \pm 0$, the highest for the recipe with $50 \mathrm{mg}$ steviocal after the basic recipe (Aggarwal et al.,2010).

\section{Gajrela incorporated with bael pulp and stevia powder by diabetics}

The overall acceptability scores given by the diabetics for gajrela prepared by incorporating $20 \%$ bael pulp and substituting sugar with stevia were found to be higher than that of semi trained panel ranging from 6.7-8.03 as compared to 6.63-7.95. The statistical analysis revealed that the sensory scores for all the sensory parameters namely appearance, colour, texture, flavor, taste and overall acceptability were significantly different for Gajrela incorporated with 20 percent bael pulp and different levels of stevia powder (Table 7). BS2 scored the highest scores for all the sensory parameters with a highest overall acceptability score of 8.03.It was followed by BS1 with an overall acceptability score of 7.54. The control scored a lower score than both BS1 and BS2 with regards to all the sensory parameters. The scores for colour were at par for $\mathrm{C}$ and $\mathrm{BS} 3$. With respect to texture, the scores were significantly different between the treatments and control. The sensory scores for taste were found to be statistically significant between the control and all the treatments, BS1 to BS4.

\section{Burfi incorporated with bael pulp}

The control sample was prepared from khoa. The bael pulp was incorporated at 20,30, 40and 50 per cent levels assigned as B1,B2,B3 and B4 respectively. Statistical datarevealed that there is a significant difference between the most acceptable sample B3 and control and other test samples in reference to taste and overall acceptability parameters as shown in table 8. Other sensory parameters like appearance, colour, texture and flavour were found to be of non significant difference in control and all other treatments. The highest mean scores for different sensory parameters of burfi were observed for B3followed by $\mathrm{C}$ and $\mathrm{B} 2$ treatments.

However, among the treatments with added bael pulp, B3 (40 per cent bael pulp) was selected as control for the standardization of kheer prepared with different proportions of stevia powder. The mean score for taste in B3 treatment was highest i.e., 7.95, followed by $\mathrm{C}$ i.e., 7.75.The least score for taste was attained by treatment with maximum percentage of bael. Flavour scores for $\mathrm{C}$ and $\mathrm{B} 3$ were observed to be at par with each other.

\section{Burfi incorporated with bael pulp and stevia powder by semi-trained panel}

The acceptable burfi incorporated with 40 per cent bael pulpfrom the first standardization was taken as the Control (C). Further, stevia powder was added to the rest of the treatments at 20,40,60 and 80per cent levels and was coded as BS1, BS2, BS3 and BS4 treatments respectively. 
Gajrela was standardized at two levels:

\section{Standardization-I}

Table.1Gajrela using different levels of bael pulp

\begin{tabular}{|l|l|l|l|l|l|}
\hline Ingredients & Gajrela & & & \\
& C & B1 & B2 & B3 & B4 \\
\hline Milk (ml) & 250 & 250 & 250 & 250 & 250 \\
\hline Carrot (g) & 100 & 90 & 80 & 70 & 60 \\
\hline Bael pulp (g) & -- & 10 & 20 & 30 & 40 \\
\hline Sugar (g) & 10 & 10 & 10 & 10 & 10 \\
\hline
\end{tabular}

C - Control (100\% carrots) $\quad$ B1- 10\% bael pulp $\quad$ B2- $20 \%$ bael pulp $\quad$ B3- 30\% bael pulp B4- $40 \%$ bael pulp

\section{Standardization-II}

Table.2Gajrela using acceptable level of bael and different levels of stevia

\begin{tabular}{|l|l|l|l|l|l|}
\hline Ingredients & Gajrela & & & \\
\cline { 2 - 6 } & C & BS1 & BS2 & BS3 & BS4 \\
\hline Milk (ml) & 250 & 250 & 250 & 250 & 250 \\
\hline Khoa $(\mathbf{g})$ & 10 & 10 & 10 & 10 & 10 \\
\hline Carrot $(\mathbf{g})$ & 80 & 80 & 80 & 80 & 80 \\
\hline Bael pulp (g) & 20 & 20 & 20 & 20 & 20 \\
\hline Sugar $(\mathbf{g})$ & 10 & 8 & 6 & 4 & 2 \\
\hline Stevia $(\mathbf{m g})$ & -- & 10 & 20 & 30 & 40 \\
\hline C - Con & & & & & \\
\hline
\end{tabular}

$\mathrm{C}-$ Control (80\% carrots $+20 \%$ bael pulp) $\quad$ BS1- $20 \%$ stevia $+80 \%$ sugar $\quad$ BS2-40\%

stevia $+60 \%$ sugar BS3-60\% stevia $+40 \%$ sugar $\quad$ BS4- $80 \%$ stevia $+20 \%$ sugar

Burfi was standardized at two levels:

\section{Standardization-I}

Table.3 Burfi using different levels of bael pulp

\begin{tabular}{|l|l|l|l|l|l|}
\hline \multirow{2}{*}{ Ingredients } & Burfi & & & \\
\cline { 2 - 6 } & C & B1 & B2 & B3 & B4 \\
\hline Milk (ml) & 1000 & 1000 & 1000 & 1000 & 1000 \\
\hline Khoa (g) & 200 & 160 & 140 & 120 & 100 \\
\hline Bael pulp (g) & -- & 40 & 60 & 80 & 100 \\
\hline Sugar (g) & 30 & 30 & 30 & 30 & 30 \\
\hline
\end{tabular}

C - Control (100\% khoa) $\quad$ B1- 20\% bael pulp $\quad$ B2- 30\% bael pulp $\quad$ B3- $40 \%$ bael pulp

B4- 50\% bael pulp 


\section{Standardization-II}

Table.4 Burfi using acceptable level of bael and different levels of stevia

\begin{tabular}{|l|l|l|l|l|l|}
\hline \multirow{2}{*}{ Ingredients } & Burfi & \multicolumn{3}{l|}{} \\
\cline { 2 - 6 } & C & BS1 & BS2 & BS3 & BS4 \\
\hline Milk (ml) & 1000 & 1000 & 1000 & 1000 & 1000 \\
\hline khoa (g) & 120 & 120 & 120 & 120 & 120 \\
\hline Bael pulp (g) & 80 & 80 & 80 & 80 & 80 \\
\hline Sugar (g) & 30 & 24 & 18 & 12 & 6 \\
\hline Stevia (mg) & -- & 30 & 60 & 90 & 120 \\
\hline
\end{tabular}

C - Control (60\% khoa+ $40 \%$ bael pulp+100\% sugar)

BS1- $20 \%$ stevia $+80 \%$ sugar $\quad$ BS2- $40 \%$ stevia $+60 \%$ sugar

BS3- $60 \%$ stevia $+40 \%$ sugar $\quad$ BS4- $80 \%$ stevia $+20 \%$ sugar

Table.5 Mean sensory scores for gajrela incorporated with bael pulp

\begin{tabular}{|l|l|l|l|l|l|l|}
\hline Samples & \multicolumn{2}{|l}{ Parameters } & \multicolumn{5}{l|}{} \\
\cline { 2 - 7 } & Appearance & Colour & Texture & Flavour & Taste & $\begin{array}{l}\text { Overall } \\
\text { acceptability }\end{array}$ \\
\hline C & 7.7 & 7.7 & 7.5 & 7.5 & 7.5 & 7.58 \\
\hline B1 & 7.5 & 7.5 & 7.5 & 7.6 & 7.6 & 7.54 \\
\hline B2 & 7.8 & 8 & 8 & 7.8 & 7.75 & 7.87 \\
\hline B3 & 7.3 & 7.35 & 7.5 & 7.55 & 7.5 & 7.44 \\
\hline B4 & 7 & 7 & 7.2 & 7.4 & 6.9 & 7.1 \\
\hline$\chi^{2}$ & $11.125^{*}$ & $16.330^{* *}$ & $12.193^{*}$ & $3.600^{*}$ & $11.385^{*}$ & $11.609^{*}$ \\
\hline
\end{tabular}

** Significant at $1 \%$ level of significance $(\mathrm{p}<0.01) \quad$ NS - Non significant

*Significant at $5 \%$ level of significance $(\mathrm{p}<0.05)$

C - Control (100\% carrots)

B1- $10 \%$ bael pulp $\quad$ B2- $20 \%$ bael pulp $\quad$ B3- $30 \%$ bael pulp $\quad$ B4- 40\%bael pulp

Table.6 Mean sensory scores for gajrela incorporated with bael pulp and stevia powder by semitrained panel

\begin{tabular}{|c|c|c|c|c|c|c|}
\hline \multirow[t]{2}{*}{ Samples } & \multicolumn{6}{|l|}{ Parameters } \\
\hline & Appearance & Colour & Texture & Flavour & Taste & $\begin{array}{l}\text { Overall } \\
\text { acceptability }\end{array}$ \\
\hline $\mathbf{C}$ & 7.6 & 7.6 & 7.5 & 7.6 & 7.65 & 7.59 \\
\hline BS1 & 7.2 & 7.25 & 7.5 & 7.45 & 7.45 & 7.37 \\
\hline BS2 & 7.9 & 8.1 & 8 & 7.8 & 7.95 & 7.95 \\
\hline BS3 & 6.9 & 6.9 & 6.9 & 7.2 & 6.8 & 6.94 \\
\hline BS4 & 6.5 & 6.6 & 6.6 & 6.9 & 6.55 & 6.63 \\
\hline$\chi^{2}$ & $24.997 * *$ & $27.421 * *$ & $31.044 * *$ & $11.358 *$ & $29.282 * *$ & $31.339 * *$ \\
\hline
\end{tabular}

$* *$ Significant at $1 \%$ level of significance $(\mathrm{p}<0.01)$

NS - Non significant

*Significant at $5 \%$ level of significance $(\mathrm{p}<0.05)$

$\mathrm{C}-$ Control ( $80 \%$ carrots $+20 \%$ bael pulp $+100 \%$ sugar)

BS1- $20 \%$ stevia $+80 \%$ sugar

BS2-40\% stevia $+60 \%$ sugar

BS3- $60 \%$ stevia $+40 \%$ sugar

BS4- $80 \%$ stevia $+20 \%$ sugar 
Table.7 Mean sensory scores for Gajrela incorporated with bael pulp and stevia powder by diabetics

\begin{tabular}{|l|c|c|c|c|c|c|}
\hline \multirow{2}{*}{ Samples } & \multicolumn{6}{|c|}{ Parameters } \\
\cline { 2 - 7 } & Appearance & Colour & Texture & Flavour & Taste & $\begin{array}{c}\text { Overall } \\
\text { acceptability }\end{array}$ \\
\hline C & 7 & 7.05 & 7.3 & 7.25 & 7.25 & 7.17 \\
\hline BS1 & 7.6 & 7.6 & 7.5 & 7.4 & 7.6 & 7.54 \\
\hline BS2 & 8 & 8.1 & 8.1 & 7.9 & 8.05 & 8.03 \\
\hline BS3 & 7 & 7 & 7 & 7.2 & 6.95 & 7.03 \\
\hline BS4 & 6.5 & 6.8 & 6.7 & 6.8 & 6.7 & 6.7 \\
\hline$\chi^{\mathbf{2}}$ & $26.318^{* *}$ & $24.461 * *$ & $26.284 * *$ & $13.326 * *$ & $20.537 * *$ & $30.087 * *$ \\
\hline
\end{tabular}

** Significant at $1 \%$ level of significance $(\mathrm{p}<0.01) \quad$ NS - Non significant

$*$ Significant at $5 \%$ level of significance $(\mathrm{p}<0.05)$

C - Control (80\% carrots+ $20 \%$ bael pulp+100\%sugar)

BS1- $20 \%$ stevia $+80 \%$ sugar BS2-40\% stevia $+60 \%$ sugar

BS3- $60 \%$ stevia $+40 \%$ sugar; BS4- $80 \%$ stevia $+20 \%$ sugar

Table.8 Mean sensory scores for Burfi incorporated with bael pulp

\begin{tabular}{|l|l|l|l|l|l|l|}
\hline Samples & Parameters & \multicolumn{5}{l|}{} \\
\cline { 2 - 7 } & Appearance & Colour & Texture & Flavour & Taste & $\begin{array}{l}\text { Overall } \\
\text { acceptability }\end{array}$ \\
\hline C & 7.7 & 8 & 7.6 & 7.6 & 7.75 & 7.73 \\
\hline B1 & 7.4 & 7.5 & 7.4 & 7.3 & 7.4 & 7.4 \\
\hline B2 & 7.3 & 7.4 & 7.6 & 7.5 & 7.7 & 7.5 \\
\hline B3 & 7.8 & 7.8 & 8 & 7.6 & 7.95 & 7.83 \\
\hline B4 & 7.1 & 7.3 & 7.4 & 7.4 & 7.3 & 7.3 \\
\hline$\chi^{2}$ & $9.346^{\mathrm{NS}}$ & $8.231^{\mathrm{NS}}$ & $6.939^{\mathrm{NS}}$ & $2.394^{\mathrm{NS}}$ & $11.460^{*}$ & $9.662^{*}$ \\
\hline
\end{tabular}

** Significant at $1 \%$ level of significance $(\mathrm{p}<0.01)$; NS - Non significant

*Significant at 5\% level of significance ( $\mathrm{p}<0.05)$; C - Control (100\% khoa) B1- 20\% bael pulp

B2-30\% bael pulp ; B3- 40\% bael pulp; B4- 50\% bael pulp

Table.9 Mean sensory scores for Burfi incorporated with bael pulp and stevia powder by semitrained panel

\begin{tabular}{|l|l|l|l|l|l|l|}
\hline Samples & \multicolumn{2}{l}{ Parameters } & \multicolumn{3}{l|}{} \\
\cline { 2 - 7 } & Appearance & Colour & Texture & Flavour & Taste & $\begin{array}{l}\text { Overall } \\
\text { acceptability }\end{array}$ \\
\hline C & 7.4 & 7.5 & 7.7 & 7.6 & 7.9 & 7.62 \\
\hline BS1 & 7 & 7.5 & 7.2 & 7.3 & 7.3 & 7.26 \\
\hline BS2 & 7.3 & 7.4 & 7.3 & 7.3 & 7.25 & 7.31 \\
\hline BS3 & 7.3 & 7.5 & 7.5 & 7.8 & 7.5 & 7.52 \\
\hline BS4 & 7.05 & 7.2 & 7.3 & 7.3 & 7.35 & 7.24 \\
\hline$\chi^{2}$ & $4.117^{\mathrm{NS}}$ & $2.846^{\mathrm{NS}}$ & $4.513^{\mathrm{NS}}$ & $6.660^{\mathrm{NS}}$ & $9.654^{*}$ & $8.939^{\mathrm{NS}}$ \\
\hline
\end{tabular}

** Significant at $1 \%$ level of significance $(\mathrm{p}<0.01) \quad$ NS - Non significant

$*$ Significant at $5 \%$ level of significance $(\mathrm{p}<0.05)$

C - Control (60\% khoa $+40 \%$ bael pulp+ $100 \%$ sugar) BS1- $20 \%$ stevia $+80 \%$ sugar

BS2-40\% stevia $+60 \%$ sugar

BS3- $60 \%$ stevia $+40 \%$ sugar

BS4- $80 \%$ stevia $+20 \%$ sugar 
Table.10 Mean sensory scores for Burfi incorporated with bael pulp and stevia powder by diabetics

\begin{tabular}{|l|l|l|l|l|l|l|}
\hline Samples & \multicolumn{2}{l}{ Parameters } & \multicolumn{5}{l|}{} \\
\cline { 2 - 7 } & Appearance & Colour & Texture & Flavour & Taste & $\begin{array}{l}\text { Overall } \\
\text { acceptability }\end{array}$ \\
\hline C & 7.5 & 7.65 & 7.3 & 7.3 & 7.35 & 7.42 \\
\hline BS1 & 7.5 & 7.5 & 7.4 & 7.4 & 7.4 & 7.44 \\
\hline BS2 & 7.5 & 7.5 & 7.7 & 7.6 & 8.1 & 7.68 \\
\hline BS3 & 7.5 & 7.7 & 7.7 & 7.9 & 7.9 & 7.74 \\
\hline BS4 & 7.2 & 7.4 & 7.3 & 7.4 & 7.5 & $7.36^{\mathrm{NS}}$ \\
\hline$\chi^{\mathbf{2}}$ & $1.826^{\mathrm{NS}}$ & $1.150^{\mathrm{NS}}$ & $3.931^{\mathrm{NS}}$ & $6.124^{\mathrm{NS}}$ & $15.992^{* *}$ & $7.863^{\mathrm{NS}}$ \\
\hline
\end{tabular}

** Significant at $1 \%$ level of significance $(\mathrm{p}<0.01) \quad$ NS - Non significant

*Significant at $5 \%$ level of significance $(\mathrm{p}<0.05)$

$\mathrm{C}-$ Control (60\% khoa+ $40 \%$ bael pulp+ $100 \%$ sugar)

BS1- $20 \%$ stevia $+80 \%$ sugar BS2-40\% stevia $+60 \%$ sugar

BS3- $60 \%$ stevia $+40 \%$ sugar BS4- $80 \%$ stevia $+20 \%$ sugar

Fig.1 Mean sensory scores for Gajrela incorporated with bael pulp and stevia powder by semi-trained panel

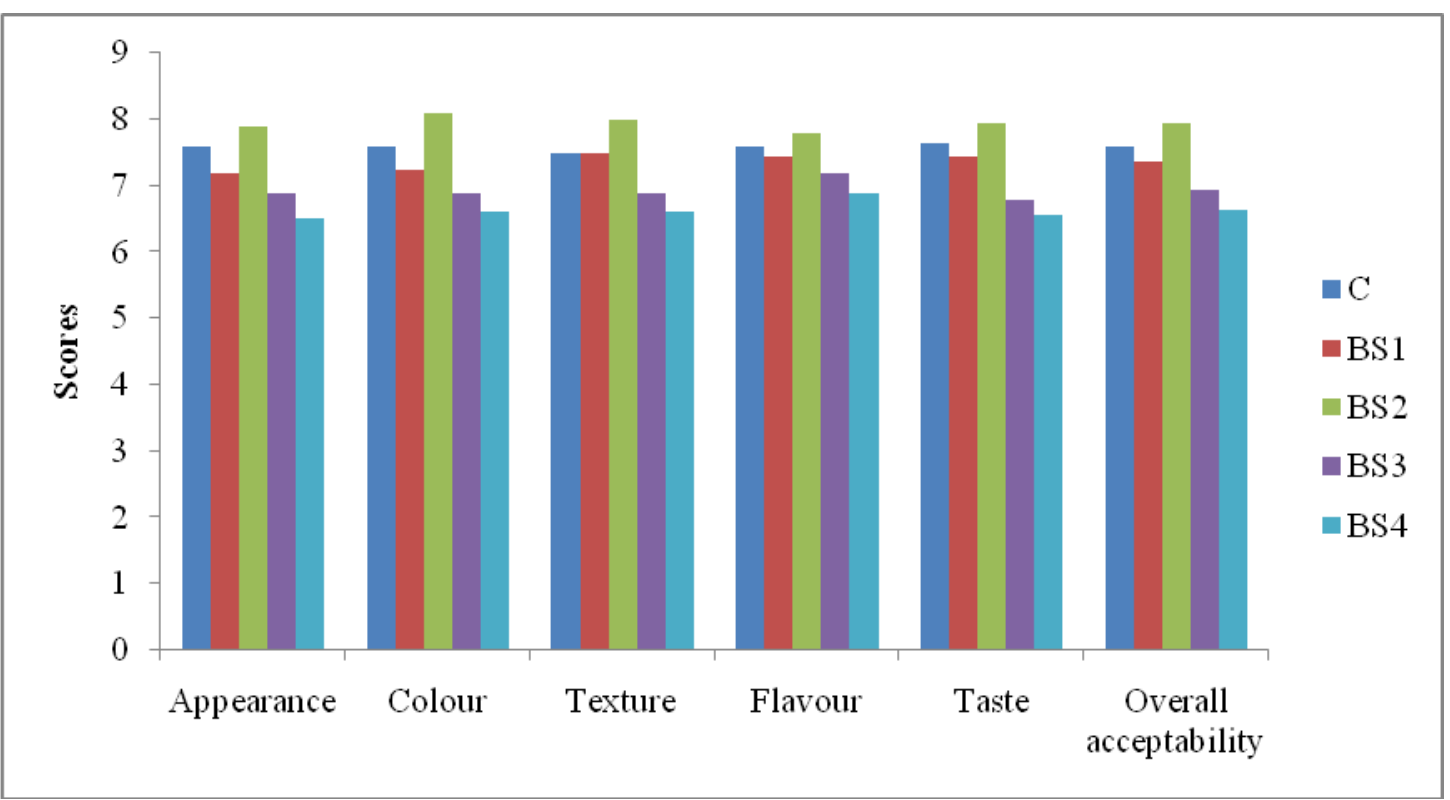


Fig.2 Mean sensory scores for Burfi incorporated with bael pulp and stevia powder by semitrained panel

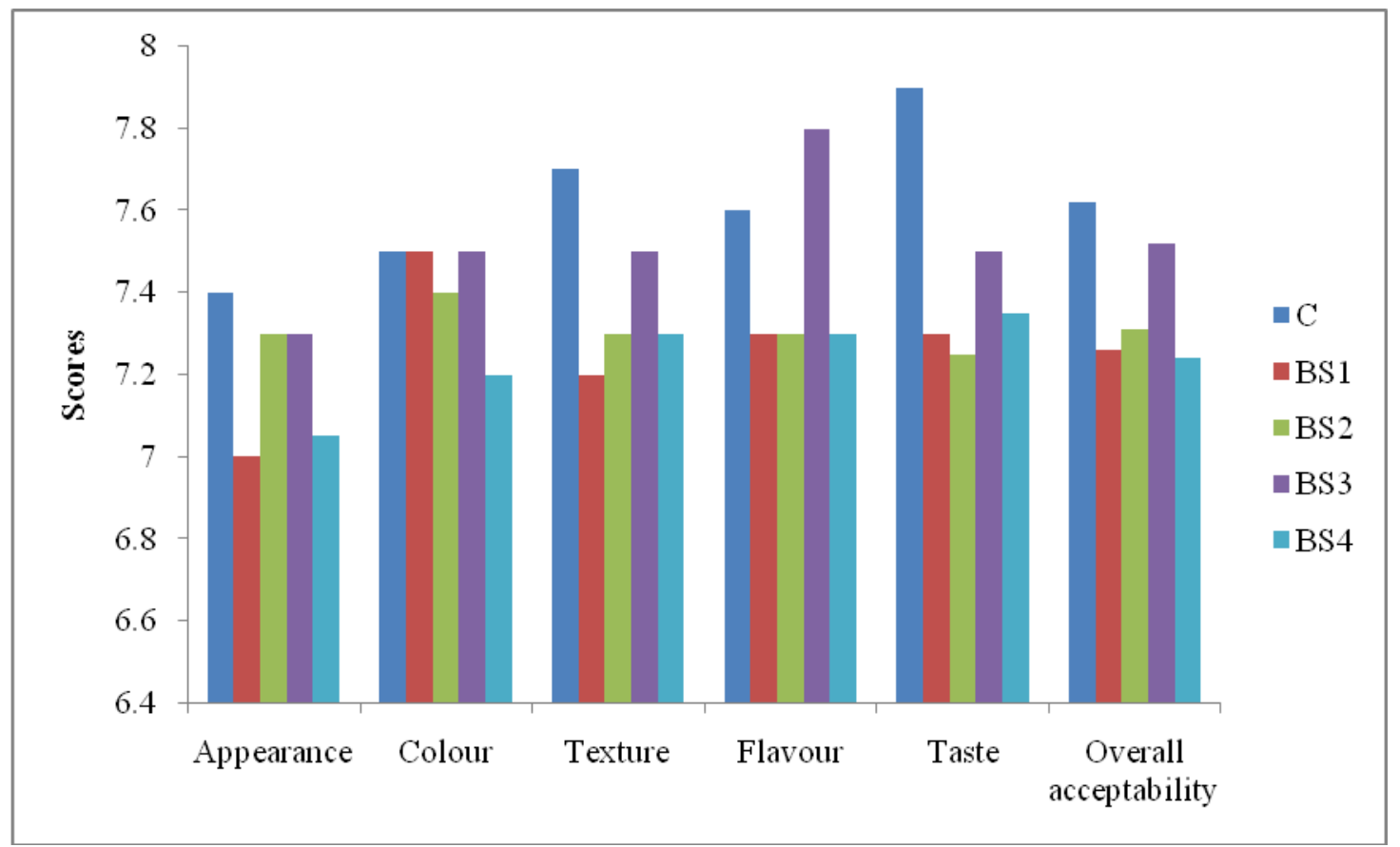

The scores for all the sensory parameters like appearance, colour, texture, flavour and taste were the highest for control (C) with an overall acceptability score of 7.62 as shown in Table 9 and Fig. 2. The analysis revealed that the sensory scores for appearance, colour, texture and flavour were not significantly different for the treatments of burfi incorporated with different levels of stevia powder. But with respect to the taste, BS3 (60 $\%$ stevia $+40 \%$ sugar) scored the highest of 7.5 after control (7.9) which was statistically significant when compared to the other treatments. It was followed by BS2 (40 per cent stevia and 60 per cent sugar) and BS1 (20 per cent stevia +80 per cent sugar). The mean scores of appearance for BS2and BS3 were at par, similarly flavour scores for BS1, BS2 and BS4 were observed to be atpar.

\section{Burfi incorporated with bael pulp and stevia powder by diabetics}

The present study concluded that incorporation of bael pulp in value added milk based sweet products i.e., gajrela at 20 and burfi at 40 per cent, was found highly acceptable.

The percentage of sugar reduced in gajrela was 40 and in burfi was 60by using stevia powder in milk based bael products. The products scored a good score on hedonic rating scale as was found to acceptable both by semi trained and diabetic panel.

\section{Recommendations}

Incorporation of bael pulp at 20 and 40 per cent in gajrela and burfi respectively and substitution of 40 and 60 per cent sugar with stevia is recommended in value added sweet products. Use of bael and stevia powder in sweet products is recommended as they are natural, safe and have many therapeutic benefits. 


\section{References}

Agarwal V(2008) Organoleptic and nutruitional evaluation of sweet products prepared using stevia powder for diabetics. M.Sc. Thesis. Punjab Agricultural University, Ludhiana Punjab.

Agarwal V, Kochhar A and Sachdeva R (2010) Sensory and nutritional evaluation of sweet milk products prepared using stevia powder for diabetics.Ethno Med 4(1): 9-13.

Charoensiddhi S and Anprung P (2008) Bioactive compounds and volatile compounds of Thai bael fruit (Aegle marmelos L. Correa) as a valuable source for functional food ingredients. Int Food Res J15(3):287-95.

Hiremarh I G, Ahn Y J and Kim Soon-II (1996), Insecticidal Activity of Indian Plant Extracts Against Nilaparvat Alugens (Homoptera Delphacidae).App Entomol Zool 32(1): 159-66.
Kim J, Choi Y H and Choi Y H (2002) Use of stevioside and cultivation of Stevia rebaudiana in Korea. In: Kinghorn AD (Ed.), Stevia, the Genus Stevia. Medicinal and Aromatic PlantsIndustrial Profiles 19: 196-202. Taylor and Francis, London and NY.

Larmond E (1970) Methods of sensory evaluation of food. Can Deptt Agric Pubs 1970:s1284.

Maity P, Hansda D, Bandyopadhyay U and Mishra D K(2009) Biological activities of crude extracts \& chemical constituents of bael Aegle marmelos (L.) Corr. Indian $J$ of Experimental Biology47:849-61.

Mandal P and Sahoo B B (2014) Studies on processing and storage stability of bael (Aegle marmelos) squash for nutritional security. J Progressive Agric 5(1):62-64.

Parichha S (2004) Bael (Aegle marmelos) Nature's Most Natural Medicinal Fruit. Orissa Rev 1:16-17.

\section{How to cite this article:}

Amarjeet Kaur, Anita Kochhar, Savita Sharma and Boora, R. S. 2019. Sensory Evaluation of Value Added Dairy Products using Bael Pulp (Aegle marmelos) and Stevia Powder. Int.J.Curr.Microbiol.App.Sci. 8(09): 2122-2131. doi: https://doi.org/10.20546/ijcmas.2019.809.246 